\title{
Characteristic-Based Development Students Aspect
}

\author{
Wahyullah Alannasir \\ Makassar Islamic University (UIM Makassar), Indonesia \\ *e-mail: wahyullah69@gmail.com
}

\begin{tabular}{l}
\hline \multicolumn{1}{c}{ Article Information } \\
\hline Received: March 19, 2020 \\
Revised: May 11, 2020 \\
Online: June 26, 2020
\end{tabular}

\section{Keywords}

student characteristics, student development

\begin{tabular}{l} 
ABSTRACT \\
\hline The characteristics of students from cognitive, affective, and \\
psychomotor aspects so that educators can cultivate and \\
develop the potential and talents of each student so that \\
educators easily evaluate the strengths and weaknesses in \\
learning. Different characteristics possessed by each student \\
can provide an understanding for each educator to use \\
strategies and methods in developing these different talents \\
and potentials. Understanding the development of student \\
characteristics can be seen from three aspects, namely \\
cognitive, affective, and psychomotor aspects. The cognitive \\
element is the domain that includes mental activities (brain). \\
Emotional issues are those related to attitudes and values, \\
which include behavioural traits such as feelings, interests, \\
beliefs, emotions, and values. Psychomotor aspects are \\
domains that include movement behaviour and physical \\
coordination, motor skills, and physical abilities ofa person so \\
that the skills that will develop if often practised can be \\
measured based on distance, speed, speed, technique, and \\
manner of implementation. Analyzing students can be seen in \\
four key factors that determine student success, including \\
general characteristics (general characteristics), specific \\
entry competencies (special initial abilities), learning styles \\
(learning styles), and multiple intelligences (plural \\
intelligence).
\end{tabular}

\section{INTRODUCTION}

A person's growth and development will occur as long as he lives. Mada growth of humans is in the physical aspects, and it happens naturally, as age increases, the child's body will increase in height. Another case with development, which occurs in the psychological aspects that lead to factors of knowledge, attitudes, and behaviour. So it can be understood that growth in the physical aspect, while the development in the psychological aspect. Each stage of development of children in the world of education is different depending on each ability possessed by students. The factors of knowledge, attitudes, and behaviour need to be considered well because it becomes a reference to assess the progress of the students' development. The most crucial child development is during the first five years or commonly referred to as the toddler age stage. After that, the child will enter the formal education stage. The concept of knowledge, attitudes, and behaviour factors is known as Bloom's Taxonomy, which was coined by Benjamin S. Bloom and friends in 1956.

Benjamin Bloom is a psychologist in education who researches and develops the ability to think of a person in a process learning. Bloom's Taxonomy is a concept of three hierarchical models that are used to classify children's educational development objectively. The three aspect models are cognitive, affective, and psychomotor. Often the teacher gives an assessment only on the cognitive aspects, so the child is always forced to know something, not understand something. In traditional classes, the teacher 
considers them the primary source of knowledge so that they do not explore the abilities and talents of their students. It happens because the teacher or educator does not understand well about the characteristics of students. Therefore, in this paper, we will discuss aspects of student development based on their personalities.

Creativity is a valuable treasure for the life of the child (Yuliani Nurani, 2010:38) because the child's creativity will live more colourful, dynamic, value, without creativity maybe life would be very monotonous and boring. Everything that exists in this life can be beautiful, fun and provide a high optimism if packaged with a touch of creativity. Creativity is very diverse because it almost any kind of job or hobby that is done by human creativity. Therefore everything in our lives is very closely related to creativity.

The immediate benefits of creativity in children is to increase creative expression, can make healthy and happy, and help solve problems in addition to improving the quality of life. Creativity is essential for children's development in the future. Seto Mulyadi (2004:17) but admits there are still many parents who are less aware of the importance of creativity for early child development. More parents want a child who is always obedient and doing the things desired by parents. Originality less acceptable and often considered dangerous. Therefore there needs to be an earnest effort and systematic in developing talent and potential to become a creative child. Creativity can be life provision and capital success in later life.

Such assessment is essential because the talent and potential can not thrive in an instant, also can not be grown in an instant of time, but it takes considerable time to the process (conditioning) to the fullest. In this context, the development of children's creativity should be started since the child is still at an early age and carried out to the fullest. To achieve the above desire, the outlines of the Program Activities Learning Kindergarten (GBPKBTK, 1994) stated that the kindergarten was established to develop all facets of the personality of the students in order to bridge the education in the family and school education. Program objectives and learning activities kindergarten children are to help lay the foundation toward the development of attitudes, knowledge, skills, and creativity (creation) required by students in adjusting to the environment.

In developing the creativity of children, kindergarten teachers serve as facilitators who guide and accompany eminent child intensely in performing its activities both in the classroom and outside the classroom (Yeni Rahmawati and Euis Kurniati, 2010:30). Nevertheless, be aware that creativity that must remain in the frame and the cultural values accepted by society. Creativity is the coveted creativity that is positive, constructive, meaningful to the lives of the next child and not contrary to social and cultural values are upheld. In developing the creativity of children, kindergarten teachers can facilitate, guide and accompany the child to conduct its activities to the fullest. However, be aware that creativity that must remain in the frame of the received values and culture in Indonesian society.

Creativity is the coveted creativity that is positive, constructive, meaningful to the lives of the next child and not contrary to social and cultural values are upheld. Exposure above illustrates two things: first, the desire of parents to have a creative child because every child has a talent for it, and secondly, most of the parents and some educators do not know the right strategy or pattern to develop the talents and potential of children so that it becomes creative. With a background as above, then in this short paper, the author tried to discuss a variety of early childhood learning strategies.

\section{METHODS}

The research method used in this study is library research done by collecting articles or scientific papers related to learning planning, learning design, learning model. This research is qualitative, by observing phenomena in Indonesia, formulating problems that occur, and then related to the obtained literature. Data collection techniques are performed by tri-formulating (combined) literature review by collecting data, exceptionally verbal data, through books, articles, notes, and various other scientific literature. The data collected are then analyzed inductively to produce grounded theory, a theory that emerges from non-hypothesis data (Setyosari, 2013). Writing steps to prepare this article: 1) Choosing a problem; 2) a preliminary study; 3) formulating a problem; formulating objectives; 4) conducting a study; 5) making a discussion; 6) formulating conclusions drawn from analysis results and recommendations for other authors. 


\section{RESULTS}

\section{Student Development on Cognitive Aspects}

Cognitive aspects are the main aspects of many educational curriculums and are benchmarks for assessing children's development. Cognitive derived from the Latin "cognition" has the meaning of recognition, which refers to the process of knowing as well as the knowledge itself. The cognitive aspect is the domain that includes mental activities (brain). All efforts concerning brain activity are included in the cognitive realm.

Cognitive aspects have six levels or aspects, namely: 1) Knowledge: This aspect is a fundamental aspect that is part of the cognitive element. Refers to the ability to recognize and remember learned material ranging from simple things to remembering theories that require a depth of thought, as well as the ability to remember concepts, processes, methods, and structures. 2) Comprehension: This aspect is higher than the element of knowledge. It refers to the ability to demonstrate facts and ideas by grouping, organizing, comparing, describing, understanding, and especially understanding the meaning of things that have been learned-understanding something that has been discovered in the form of translation (changing structures), interpretation (explaining or summarizing), and extrapolation (expanding the meaning of one material). 3) Application: The purpose of this aspect is to apply the material that has been learned using the rules and principles of the content in new conditions or real conditions-also the ability to utilize certain abstract concepts and ideas or theories. Application is a higher level than the two previous aspects, namely knowledge and understanding. 4) Analysis: Analyzing involves testing and breaking down information into several sections, determining how one part relates to another element, identifying motives or causes, and making conclusions and supporting material for these conclusions.

Three characteristics exist in the aspect of analysis, namely elemental analysis, relationship analysis, and organizational analysis. 5) Synthesis: Synthesis includes explaining structures or patterns not seen before, and also being able to disclose the data or information obtained. In other words, aspects of synthesis include the ability to unite concepts or components so that they can form a structure that has a new pattern. In this aspect, the creative side of a person or student is needed. 6) Evaluation: Assessment is the ability to think and provide judgment and consideration of material values for a particular purpose. Alternatively, in other words, the ability to judge something for a specific purpose. This evaluation is based on internal and external criteria.

The purpose of cognitive aspects is oriented to the ability to think that includes more simple intellectual skills, namely remembering to the ability to solve problems that require students to connect and combine several ideas, ideas, methods, or procedures learned to solve the problem. Thus, the cognitive aspect is the sub taxonomy that reveals mental activities that often start from the level of knowledge to the highest level, namely evaluation. The increasing age of the child will be followed by cognitive development. According to Jean Piaget (1981), there are four stages of a child's cognitive development, namely: (1) motor sensory stage (age 0-2 years); (2) preoperational stage (age 2-7 years); (3) concrete operational steps (aged 7-11 years); and (4) formal operational stage (ages 11 and over). These four developments are inseparable because they occur continuously.

\section{Student Development on Affective Aspects}

Affective aspects are those related to attitudes and values. The affective domain includes behavioural traits such as feelings, interests, beliefs, emotions, and values. Besides, someone's affective will be reflected in their attitudes and perceptions, which include: (1) self-concept and self-esteem; (2) self-efficacy and contextual efficacy; (3) attitude of self-acceptance and others acceptance. Self-concept or self-concept is the totality of a person's attitudes and perceptions of himself. In comparison, selfesteem or self-esteem is the level of one's views and judgments about his quality based on his achievements. This attitude reflects that someone understands himself truthfully so that the philosophy of self-respect emerges as a human being. Self-efficacy is one's belief in the effectiveness of one's own ability to arouse the passion and activities of others.

In contrast, contextual efficacy is a person's ability to deal with the limitations of external factors at a particular time. This attitude reflects that someone's perspective can influence others so that the approach displayed by someone can be imitated and valued by others. The philosophy of self-acceptance is a symptom of a person's feelings in a positive or negative tendency towards oneself based on an honest assessment of their talents and abilities. At the same time, another acceptance is the attitude of 
being able to accept the existence of others, which is strongly influenced by the ability to recognize oneself. This attitude is reflected in a person understanding his strengths honestly so that he can accept the existence of other people who are different from their talents. The affective aspects are further described in five levels, namely:

1. Receiving or attending

It refers to the ability to pay attention and respond to appropriate stimulation, as well as the ability to show consideration or respect for others. In the affective domain or domain, acceptance is the lowest learning outcome. For example, I am listening to other people's opinions.

2. Responding

This domain is one level above acceptance, and this will be seen when students become involved and interested in a material. Children can participate in learning activities and always have the motivation to react and take action. For example: participating in a class discussion about a lesson.

3. Valuing (valuing or appreciating)

This domain refers to the importance of value or attachment to something, such as acceptance, rejection, or not expressing an opinion. Also the ability to communicate what is right and not good from an activity or event and show it into behaviour. For example: proposing group activities for a subject matter.

4. Organization (regulate or organize)

The purpose of the corporate realm is the unification of values. These different attitudes make children more consistent and form their internal value systems and resolve conflicts that arise between them. Also, harmonize the differences in existing values and align the differences.

5. Characterization by a value or value complex

This domain reference is a person's character and life force. All of this will be reflected in behaviour that has to do with personal, social, and emotional order. Values have evolved so that action is more natural to predict.

\section{Development of Students on Psychomotor Aspects}

The psychomotor aspect is the domain that is related to the skills or ability to act after a person has received specific learning experiences. Psychomotor learning outcomes are a continuation of cognitive learning outcomes (understanding something) and affective learning outcomes (which only appear in the form of behavioural tendencies). The psychomotor domain is related to physical activities, such as running, jumping, painting, dancing, hitting, and so on.

Loree states that two main types of psychomotor behaviour are universal and must be mastered by each individual in infancy or early childhood is walking and holding objects (prehension). Both types of psychomotor skills are the basis for the development of more complex skills as we know them as playing and working. Gessel explains that motor behaviour includes body movements, coordination, and exceptional motor skills. Learning outcomes from psychomotor aspects can be measured through: (1) direct observation and assessment of students' behaviour during the practical learning process, (2) after participating in learning, namely by providing tests to students to measure knowledge, skills, and attitudes, and (3) sometime after education is finished and later in the work environment. Psychomotor is a domain that includes movement behaviour and physical coordination, motor skills, and physical abilities of a person. These skills that will develop if often practised can be measured by distance, speed, speed, technique, and manner of implementation. In the psychomotor aspect, seven categories are ranging from the lowest to the highest.

1. Impersonation

This category occurs when the child can interpret the stimulus or sensor into a motor movement. Children can observe a campaign and then begin to respond to what is seen in the form of imitating movements; the imitation form is not specific and imperfect.

2. Readiness

Children's readiness to move includes mental, physical, and emotional aspects. At this level, children display things according to the instructions given and not just imitate. The child also shows the choice movements he masters through the exercise process and determines his response to certain situations. 


\section{Guided Response}

It is the initial stage in the process of learning complex movements, which include imitation, as well as the process of experimental demonstrations. Success in performance is achieved through continuous practice.

\section{Mechanism}

It is an intermediate stage in learning a tricky ability. At this stage, the response learned has become a habit, and the movement can be done with particular confidence and accuracy.

\section{Response Looks Complex}

This stage of skilled motor movement involves complex patterns of movement. Movement skills are indicated by accurate and coordinated appearance, but with minimal effort. Judgments include ongoing and automatic changes.

6. Adaptation

At this stage, motor mastery has entered a part where children can modify and adjust their skills to develop in a variety of different situations.

7. Creation

They are creating various modifications and new movement patterns to suit the demands of a situation. The learning process generates new things or movements by emphasizing creativity based on rapidly developing abilities.

\section{DISCUSSION}

Humans are created with a variety of uniqueness or characteristics that distinguish between one person and another person. In general, this can be seen in the differences in culture, ethnicity, religion, gender, social status, and so on, which can be analyzed thoroughly.

The identification of student characteristics needs to be done based on a juridical and theoretical foundation. First, Government Regulation No. 19 of 2005 concerning National Education Standards, "the development of learning is done by taking into account the demands, talents, interests, needs, and interests of students. Second, students theoretically differ in many ways, which include differences in individual nature, in addition to differences in family, social, cultural, economic, and environmental backgrounds. In analyzing students, according to Muhammad Yaumi, four key factors determine student success, including general characteristics, specific entry competencies, learning styles, and multiple intelligences.

1. General Characteristics

General characteristics describe the condition of students, such as age, class, occupation, and gender. Student characteristics refer to unique traits possessed by students, where these characteristics can affect the level of success in achieving learning goals. Student characteristics are unique characteristics possessed by each student either as individuals or groups as a consideration in the process of organizing learning. Winkel links the aspects of students with the mention of initial conditions, where the initial conditions not only include the reality of each student but also the fact of each teacher. The following will be explained about student development in terms of age, physical, psychomotor, and academic for children in elementary school, as follows:

a. Physical Development

The physical or human body is a complex organ system and very admirable. All of these organs are formed in the prenatal period (in the womb). In connection with this physical development Kuhlen and Thompson (Hurlock, 1956) suggest that the individual's physical development includes four aspects, namely (1) the nervous system, which significantly influences the development of intelligence and emotions; (2) muscles, which affect the development of strength and motor skills; (3) Endocrine glands, which cause the emergence of new patterns of behaviour, such as in adolescence develop a feeling of pleasure to be active in an activity, which consists of members of the opposite sex; and (4) physical or bodily structures, which include height, weight, and proportions.

b. Psychomotor Development

The two main developmental principles that appear in all forms of psychomotor behaviour are that they progress from simple to complex, as well as gross and global (gross bodily movements) to those that are subtle and specific but finely coordinated movements. 
c. Academic Development.

The characteristics of academic development are explained using the stages of cognitive development, according to Piaget. Academic ability is related to how the brain works.

2. Specific Initial Competence (Specific Entry Competence)

The initial ability of students is the actual abilities possessed by students before following the teaching and learning process. Analysis of students' initial ability activities carried out to search for and find information or data about the abilities of students before participating in teaching and learning activities in the classroom. This activity is beneficial to achieve the final results owned by students (the ultimate strength of students following specific and general instructional goals).

The teaching and learning process must bridge between the students 'initial abilities and the students' final abilities. Example: Grade 1 students in elementary schools can say zero through nine (09), but they may not necessarily add, subtract, or multiply. Specific initial competency (Specific Entry Competence), namely, knowledge and skills possessed / not possessed by students-prerequisite knowledge, targeted abilities, and attitudes. Educators must understand the initial competence of students before participating in the learning given. They come to class with different knowledge, skills, beliefs, and attitudes. It affects how they present, interpret and manage the information obtained. How to find out the initial capabilities, namely:

a. Simple questions, namely asking specific topics in class.

b. Formal tests that are developed from the previous material.

c. Prerequisite tests, to find out to able the next program.

3. Learning Styles

Learning styles are specific ways in which an individual learns. The preferred or best way to think, process information, and demonstrate learning. Tools chose by individuals to gain knowledge and skills. Habits, strategies, or normal mental behaviour about education, or it could be psychological traits that affect how students view and respond to various stimuli provided. Learning styles can be classified into the tendencies and speed possessed by someone in processing specific types of information. Classification of individual learning styles is based on the ability to understand certain types of information, namely learning styles: (1) visual, (2) additive, and (3) kinesthetic. More specific kinds of learning styles will be discussed below, as follows:

a. Visual Learners

They learn things best through vision. They are having difficulty absorbing information through verbal presentations without accompanied by visual images. Need visual aids or props that they can see and witness firsthand. Their learning methods include: Remembering what was observed rather than heard; Like to scribble on something; Fast and assiduous reader; Prefers reading rather than reading; Neat and orderly; Concerned about appearance; Be careful of details; Good spelling; Understand pictures and charts more than written instructions; Know what to say but do not think of the right word; Usually not bothered by noise, and; Remembering with the visual association.

b. Auditory Learners

They learn something best through hearing. Prefer the presentation of material through lectures and discussions. Usually focused on one problem at a time, easy to lose concentration if there is interference, do not like large groups, and project-based tasks. The way they learn, among other things: It absorbs faster by listening; Move the lips and say the writing in the book when reading; It is a pleasure to read aloud and listen; Can repeat and mimic the tone, rhythm, and color of the sound; Good at talking and telling stories; Speaking with a patterned rhythm; Considering what was discussed rather than what was seen; Likes to chat, discuss and explain something at length; It is better at spelling out loud than writing it; Like music and singing; Cannot stay still for a long time, and; Likes to do group assignments.

c. Kinesthetic Learners

They do physical activities, like moving and moving during learning. To write by hand, and the most important thing is to use limbs in education. They like to move, shake their heads, hands, feet. They are happy with the role-playing method, dominant in sports, acting, and theater. The way they learn, among other things: Always physically oriented and move a lot; Speak slowly; Like to use various equipment and media; Touching people to get their attention; Stand close when 
talking to people; Learning through practice; Memorizing by walking and seeing; Using fingers as a pointer when reading; Many use body cues; Unable to sit still for long periods; Want to do everything, and; Like games and sports.

4. Multiple Intelligences

Gardner put forward the concept of multiple intelligences or multiple intelligences that can distinguish learning tendencies and interests that one has from others. According to Gardner, compound intelligence has several aspects, namely: (1) logical-mathematical intelligence (2) visual/spatial intelligence (3) kinesthetic intelligence of the body (4) musical / rhythmic intelligence (5) verbal/linguistic intelligence (6) interpersonal intelligence (7) ) intrapersonal intelligence and (8) naturalistic intelligence.

Various abilities, skills, or talents that a person has to solve different problems faced. Invented by Howard Gardner (1983) includes seven bits of intelligence, namely: verbal-linguistic, mathematicallogical, bodily-kinesthetic, visual-spatial, rhythmic-musical, interpersonal, and intrapersonal. He added one more intelligence (1999), namely naturalistic intelligence, and allowed for existential information known as half intelligence (half intelligence). So named because he does not yet fully have factual data, which implies that scientifically existential intelligence is a part of plural knowledge. The plural intelligence referred to can be grouped as follows:

a. Interactive Domain

Referring to the ability of individuals to interact with other individuals by using verbal-linguistic, interpersonal, and bodily-kinesthetic intelligence possessed. Verbal is understood as the ability to express themselves verbally and in writing, while linguistics is the ability to use language. Bodilykinesthetic is the ability to use the whole body in expressing ideas, feelings, and using hands to produce or transform something. Interpersonal is the ability to understand the thoughts, attitudes, and behaviour of others. People who have low intelligence in this domain will have difficulty interacting with others.

b. Analytic Domain

It refers to the ability to think logically, which involves rational reasons that include logicalmathematical, rhythmic-musical, and naturalist intelligence. Logical-mathematical is the ability to sequence reasons, recognize patterns and rules. Rhythm-music is the ability to think by using music, listening to models, and getting to know and maybe manipulating them. The naturalist is the ability to make categorization and hierarchy about an organism, such as plants, animals, and nature.

c. Introspective Domain

It can be achieved with a natural affective process, meaning that it involves the involvement of emotional aspects to see something more profound than just looking but is able to make an emotional connection between what is happening with past experience, includes visual, intrapersonal, and existential intelligence. Includes visual-spatial knowledge, which is the ability to perceive the visual-spatial world accurately and to transform the visual-spatial perception in various forms. This ability provides sensitivity to lines, colours, shapes, spaces, balance, patterns, and relationships between elements. Intrapersonal intelligence is the ability to understand oneself and act on that understanding. It is an inner intelligence that is based on a comprehensive understanding of self in order to face, plan, and solve various problems encountered.

\section{CONCLUSION}

Understanding the development of student characteristics can be seen from three aspects, namely cognitive, affective, and psychomotor aspects. The cognitive element is the domain that includes mental activities (brain). Emotional issues are those related to attitudes and values, which include behavioural traits such as feelings, interests, beliefs, emotions, and values. Psychomotor aspects are domains that include movement behaviour and physical coordination, motor skills, and physical abilities of a person so that the skills that will develop if often practised can be measured based on distance, speed, speed, technique, and manner of implementation. Analyzing students can be seen in four key factors that determine student success, including general characteristics (general characteristics), specific entry competencies (special initial abilities), learning styles (learning styles), and multiple intelligences (plural intelligence). 


\section{REFERENCES}

Adisusilo, Sutarjo. (2014). Pembelajaran Nilai Karakter (Konstruktivisme dan VCT sebagai Inovasi Pembelajaran Afektif). Jakarta: Rajawali Pers,.

Bloom. Benjamin, S. (1972). Taxonomy of Education Objectivities (The Classification of educational Goal). New York: David McKay Company, Inc.

Porter, Bobbi De dan Mike Hernacki. (2009). Quantum Learning Membiasakan Belajar Nyaman dan Menyenangkan. (Terj. Alwiyah Abdurrahman Original Title Quantum Learning: Unleshing the Genius in You). Bandung: Kaifa.

Pribadi, Beny A. (2011) Model Assure untuk Mendesain Pembelajaran Sukses, Jakarta: Dian Rakyat,.

Riyanto, Yatim. (2013) Paradigma Baru Pembelajaran: Sebagai Referensi bagi Guru/Pendidik dalam Implementasi Pembelajaran yang Efektif dan Berkualitas. Jakarta: Prenada Media Group,.

Salkind, Neil J. (2010) Teori Perkembangan Manusia Pengantar Menuju Pemahaman Holistik, Bandung: Nusa Media.

Sanjaya, Wina. (2013)Perencanaan dan Desain Sistem Pembelajaran, Jakarta: Kencana Prenada Media Group.

Suryabrata, Sumadi. (2014). Psikologi Pendidikan. Jakarta: Rajawali Pers.

Syah, Muhibbin. (2007). Psikologi Pendidikan dengan Pendekatan Baru. Bandung: PT Remaja Rosdakarya.

Winkel, W.S. (2014). Psikologi Pengajaran, Yogyakarta: Sketsa.

Yaumi, Muhammad. (2014). Prinsip-prinsip Desain Pembelajaran: Disesuaikan dengan Kurikulum 2013 (Edisi Kedua). Jakarta: Kencana. 